\title{
Hydralazine reduces myocardial tissue damage in rats submitted to chronic inhibition of systemic nitric oxide synthesis during 4,14 and 28 days
}

\author{
Hidralazina reduz lesões teciduais miocárdicas em ratos submetidos à inibição crônica da síntese sistêmica do \\ óxido nítrico durante 4, 14 e 28 dias
}

\section{key words}

Nitric oxide

L-Name

Arterial hypertension

Cardiac hypertrophy

Heart morphology

Cardiomyopathy

Arteriosclerosis

\author{
Ricardo Xavier-Vidal ${ }^{1-4}$ \\ Kalil Madi ${ }^{1,3}$ \\ Aline de Abreu Reis ${ }^{2,3}$ \\ Leandra da Silva Paes, ${ }^{2,3}$ \\ Ana Carolina de Azevedo Carvalho $0^{2,3}$ \\ Nádia Maria S. Marques ${ }^{2}$ \\ Marcelo Guimarães ${ }^{2}$ \\ Marcelo Aranha Gardel ${ }^{2}$ \\ Sonia Oliveira Souza ${ }^{3}$ \\ Simone Marques Fernandes, 3 \\ Fernanda Oliveira Laranjeira ${ }^{2,3}$
}

\section{abstract}

The aim of the present work was to develop a qualitative chronopathological study concerning

abnormalities in myocardium, due to nitric oxide (NO) blockage. We used 60 Wistar normotensive young

male rats from several breeds. Groups of rats were submitted to $L-N a m e(L)$ via oral administration dissolved

in water $(750 \mathrm{mg} / \mathrm{l})$ during days 4,14 and 28 . Other groups were submitted concomitantly to L-Name and

hydralazine hydrocloride $(\mathrm{L}+\mathrm{H})(120 \mathrm{mg} / \mathrm{l})$. On days 4 and 14 ( $\mathrm{L}$ group) we have found myocardial

abnormalities and lesions while in $\mathrm{L}+\mathrm{H}$ we could not identify abnormalities. Considering $\mathrm{L}$ group on day

28 , the myocardium presented characteristic fibrosis (reactive and reparative), vascular damage with

increasing wall thickness due mainly to proliferation of the arterial smooth muscle cell. Total obliteration of

vessels was noted only in this period. We also observed reactive fibrosis between muscle cells of the vascular wall and proliferation of cells in the intimal layer. $\ln \mathrm{L}+\mathrm{H}$ (day 28), similar vascular abnormalities described for $L$ group (less frequent and less apparent) were also observed. In $\mathrm{L}+\mathrm{H}$ we did not identify total vascular obstructions. In $\mathrm{L}+\mathrm{H}$, infarct areas were not observed. Control groups did not present any abnormalities. Our results support the idea that, at least in some cases, hypertrophy vascular abnormalities and myocardial lesions in arterial hypertension can occur because of the reduction in organic nitric oxide production. Our results also suggested that these morbid processes can be postponed by the use of hydralazine which, however, does not avoid abnormalities after long-term experimental blockage of NO. 


\section{Introduction}

The nitric oxide (NO) is an endothelium vasorelaxing factor and its deficit is involved in some human morbid processes. The L-Name - $\mathrm{N}^{\omega}{ }^{\omega}$-nitro-arginine-methyl-ester - is an analog and antagonist of L-Arginine (substract of NO) and via oral or parenteral administration interrupts the NO synthesis which is necessary for maintenance of normal arterial pressure. That causes arterial hypertension, cardiac hypertrophy, vascular abnormalities and lesions in the myocardium (1-6). Nowadays the degree of direct influence of $\mathrm{NO}$ and the influence of its hypertension in the origin of lesions found in heart and vessels is disputed. Since the reduction of arterial hypertension in this model does not reduce significantly the cardiac and vascular abnormalities, these morbid processes are probably related mainly to NO deficit and not to hypertensive processes $(1,3-6)$. Moreno Jr. et al. $(3,5)$, using L-Name + enalapril, identified that enalapril avoided arterial hypertension and ventricular hypertrophy; however, did not avoid the development of myocardial lesions. Numaguchi et al. (1) showed that on day 56 of concomitant submission to LName and hydralazine, necrotic areas and reparative fibrosis in rats' myocardium occurred. Felix et al. (7), utilizing infused dosis of aldosterone and angiotensin II in rats, found similar reactive and reparative fibrosis which were also similar to the changes noted in our previous (6) work. However, the beginning of this process is not wellknown. In other words, does addition of hydralazine delay the beginning of arterial and myocardian lesions or not?

The aim of this work is to develop a qualitative chronopathological study in rats' myocardium submitted to L-Name or L-Name + hydralazine during days 4, 14 and 28.

\section{Material and methods}

A total of 60 normotensive young adults Wistar rats from several breeds were used. Tail arterial pressures were obtained using hydraulic pletismography (6). Initially, the pressure of all animals was not above $119 \mathrm{mmHg}$. After checking arterial pressure and weight, each animal was placed in individual plastic boxes. To perform nitric oxide blockage we utilized L-Name (hydrochloride of $\mathrm{N}^{\omega}{ }^{\omega}$-nitroL-arginine methyl ester, Sigma Chemical) via oral administration, concentration of $750 \mathrm{mg} / \mathrm{l}$ in drinking water (about $60-80 \mathrm{mg} / \mathrm{Kg}$ of rat's body weight a day $(6,8)$ ). To prevent hypertension we utilized hydralazine hydrocloride (Sigma Chemical), concentration of $120 \mathrm{mg} / \mathrm{l}$ (1) in drinking water solution (same bottle of L-Name). On days 4,14 and 28, the rats' arterial pressure and weight were measured, they were anesthetized with ethylic ether and necropsies were performed. The hearts were weighed and fixed in formaldehyde $4 \%$ buffered $\mathrm{pH}$ 7.2-7.4, processed using routine methods, embedded in paraffin, sectioned in 4, 5 or $8 u \mathrm{~m}$ and stained using: hematoxilin-eosin, Masson's trichrome, picro-sirius red polarization, Weigert's resorcinol fuchsin solution (with and without oxon). The treatment with Weigert's resorcinol fuchsin solution using oxon (10\% in water solution during $45 \mathrm{~min}$ ) is important because the oxon produces oxidation which reveals the oxytalan fibers in violet $(9,10)$. Large amounts of oxytalan fibers suggest increasing stiffness of tissue because these fibers are the less stretching of the elastic fibers. The picrosirius red technique was performed following Dolber and Spach $(11,12)$.

Group 1 (4 days): 21 rats were used. Eight rats were submitted to L-Name (group $1 \mathrm{~L}$ ). Seven rats were submitted concomitantly to L-Name plus hydralazine hydrocloride (group $1 \mathrm{~L}+\mathrm{H}$ ). Six rats were used as control group (group 1C). Group 2 (14 days): 19 rats were utilized. Seven rats were submitted during 14 days to L-Name (group $2 \mathrm{~L}$ ). Six rats were submitted concomitantly to L-Name plus hydralazine hydrocloride (group $2 \mathrm{~L}+\mathrm{H}$ ). Six rats were used as control group (group 2C). Group 3 (28 days): 21 rats were used. Eight rats were submitted to L-Name (group 3L). Seven rats were submitted to L-Name plus hydralazine hydrocloride (group $3 \mathrm{~L}+\mathrm{H}$ ). Six rats were used as control group (group 3C) (Tables 1 and 2). Anova one way, following Duncan Test of multiple comparisons, was utilized to statistical evaluations using software Statistica version 5.5, copyright 1984-2000 by Statsoft, Inc.

\section{Results}

\section{Water ingestion, arterial blood pressure, body weight and cardiac weight}

Our results (Table 3 ) show a similar ingestion of water for control (C) (33.24ml) and L-Name (L) $(33.52 \mathrm{ml})$ groups $(p>0.05)$. Nevertheless, comparing $C(33.24 \mathrm{ml})$ with L-Name + hydralazine hydrocloride $(\mathrm{L}+\mathrm{H})(28.01 \mathrm{ml})$ we found significant reduction in water ingestion from $\mathrm{C}$ to $\mathrm{L}+\mathrm{H}$ groups $(p<0.001)$. Concerning arterial pressure (Table 1), group 1 had no significant difference comparing $1 \mathrm{C}$ with $1 \mathrm{~L}$ and $1 \mathrm{C}$ with $1 \mathrm{~L}+\mathrm{H}(p>0.05)$. In group 2, comparing $2 \mathrm{C}$ with $2 \mathrm{~L}$, we found significant difference on day $6(p<0.05)$ and also on day $13(p<0.001)$ of submission. 


\section{Tail-cuff arterial pressure ( $\mathrm{mmHg}$ ) measured using a hydraulic pletismography}

Table 1 (mean/standard error)

\begin{tabular}{|c|c|c|c|c|c|}
\hline & Control & $\mathbf{L}$ & $p$ & $\mathrm{~L}+\mathrm{H}$ & $p$ \\
\hline \multicolumn{6}{|c|}{ Group 1: Control $(n=6) ; L(n=7) ; L+H(n=7)$} \\
\hline Initial AP & $106.2 / 3.6$ & $106.6 / 2.3$ & $>0.05$ & $106 / 3.1$ & $>0.05$ \\
\hline Final AP & $108.5 / 2.7$ & $110.1 / 2.7$ & $>0.05$ & $106.9 / 2.3$ & $>0.05$ \\
\hline \multicolumn{6}{|c|}{ Group 2: Control $(n=6) ; L(n=7) ; L+H(n=6)$} \\
\hline Initial AP & $104.2 / 3.9$ & $111.4 / 1.2$ & $>0.05$ & $103 / 3.9$ & $>0.05$ \\
\hline AP day 6 & $111.5 / 1.8$ & $121.4 / 1.9$ & $<0.05$ & $106.2 / 2.9$ & $>0.05$ \\
\hline AP day 13 & $106.3 / 2.6$ & $145.9 / 3.5$ & $<0.001$ & $111.7 / 4.4$ & $>0.05$ \\
\hline \multicolumn{6}{|c|}{ Group 3: Control $(n=6) ; L(n=8) ; L+H(n=7)$} \\
\hline Initial AP & $111.2 / 2$ & $103.6 / 2.4$ & $<0.05^{* *}$ & $104.4 / 1.8$ & $<0.05^{* *}$ \\
\hline AP day 6 & $110.5 / 3.1$ & $115.1 / 2.4$ & $>0.05$ & $98.6 / 3.7$ & $<0.05^{* *}$ \\
\hline AP day 13 & $114.2 / 1$ & $141.6 / 5$ & $<0.001$ & $113.4 / 2.7$ & $>0.05$ \\
\hline AP day 20 & $105.3 / 1.8$ & $165 / 4.9$ & $<0.001$ & 111.1/ 3 & $>0.05$ \\
\hline AP day 27 & $106.5 / 1.9$ & $200.5 / 3.1 *$ & $<0.001$ & $112.3 / 3$ & $>0.05$ \\
\hline
\end{tabular}

AP: arterial pressure; L: submitted to L-Name; L + H: submitted to L-Name + hydralazine; $p=$ test of similarity evaluating the probability of arterial pressure of control group compared with groups submitted to L-Name and L-Name + hydralazine being equal to zero; ${ }^{*} n=6$, two animals presented intense paralysis of the limbs and because of terminal stage of that were killed, one on day 24 and the other on day 27 ; ${ }^{* *}$ note that this arterial pressure had a significant inferior value comparing with control group.

\section{Table 2 Body weight during the experiments (mean/standard error of mean)}

\begin{tabular}{|c|c|c|c|c|c|c|}
\hline & Control & L & $p$ & $L+H$ & $p$ & $\mathrm{p}(\mathrm{L} \times \mathrm{LH})$ \\
\hline \multicolumn{7}{|c|}{ Group 1: Control $(n=6) ; L(n=7) ; L+H(n=7)$} \\
\hline Initial & $240.8 / 8$ & $237 / 5.1$ & & $215.7 / 13.6$ & & \\
\hline Final & $288.7 / 6.6$ & $278.1 / 5.9$ & & $260.9 / 12.7$ & & \\
\hline Final/initial & $47.8 / 4.3$ & $41.1 / 6.2$ & $>0.05$ & $45.14 / 9.5$ & $>0.05$ & $>0.05$ \\
\hline Variation (\%) & 16.6 & 14.9 & & 17.3 & & \\
\hline \multicolumn{7}{|c|}{ Group 2: Control $(n=6) ; L(n=7) ; L+H(n=6)$} \\
\hline Initial & $152.1 / 6.7$ & $194.3 / 3.5$ & & $195 / 6.96$ & & \\
\hline Day 7 & 188.9/7.2 & $211.7 / 9.6$ & & $228.4 / 11.3$ & & \\
\hline Day 14 & $215.4 / 10.2$ & $226 / 14.2(n=6)^{*}$ & & $244.5 / 12.7$ & & \\
\hline Final/ initial & $63.3 / 5$ & $31 / 6.9$ & $>0.05$ & $48.7 / 18.7$ & $>0.05$ & $>0.05$ \\
\hline Variation (\%) & 29.4 & 14 & & 20.3 & & \\
\hline \multicolumn{7}{|c|}{ Group 3: Control $(n=6) ; L(n=8) ; L+H(n=7)$} \\
\hline Initial & $211.7 / 4.4$ & $213.5 / 4.9$ & & $205 / 15.7$ & & \\
\hline Day 7 & $255 / 9.1$ & $239.9 / 7.4$ & & $230.4 / 7$ & & \\
\hline Day 14 & $278.7 / 7.8$ & $258 / 10.1$ & & $241.6 / 4.9$ & & \\
\hline Day 21 & $294.8 / 9.1$ & $269.9 / 12.2$ & & $257.1 / 6.4$ & & \\
\hline Day 27 & $312.7 / 10.6$ & $271 / 12.1(n=7)^{* *}$ & & $260.7 / 6.2$ & & \\
\hline Final/ initial & $101 / 7.2$ & $56.14 / 14$ & $<0.05$ & $55.71 / 16.3$ & $<0.05$ & $>0.05$ \\
\hline Variation (\%) & 32.3 & 21.2 & & 21.4 & & \\
\hline
\end{tabular}

L: submitted to L-Name; L + H: submitted to L-Name + hydralazine; final/initial: difference between final and initial body weight. In these procedures were utilized: $n=6$ in group 2 and $n=7$ in group 3 ; *it was not possible to evaluate the weight of one of the animals; **one animal presented great paralysis of all limbs and, in terminal stage, was killed on day 24. 


\section{Table 3 Mean of daily water ingestion $(\mathrm{ml})$ during the experiments (mean/standard error of mean)}

$\begin{array}{lcccc}\text { Control } & L & p & L+H & p \\ 33.24 / 0.66(n=42 \text { days*) } & 33.52 / 0.68(n=43 \text { days**) } & >0.05 & 28.01 / 0.64(n=43 \text { days***) } & <0.001 \\ \min =23 / \max =42.9 & \min =22.4 / \max =43.2 & & \min =15 / \max =37.3 & \end{array}$

L: submitted to L-Name; L + H: submitted to L-Name + hydralazine; min: minimum value; max: maximum value; $p=$ test of similarity evaluating probability of arterial pressure of control group compared with groups submitted to L-Name and L-Name + hydralazine being equal to zero; *mean of 3 days (1C) +13 days ( $2 \mathrm{C}$ ) +26 days ( $3 \mathrm{C})$. Sum equal to 42 days. A total of 20 control rats; ${ }^{* *}$ mean of 3 days $(1 \mathrm{~L})+13$ days $(2 \mathrm{~L})+27$ days $(3 \mathrm{~L})$. Sum equal to 43 days. $\mathrm{A}$ total of $19 \mathrm{~L}-\mathrm{Name}$ rats; ${ }^{* * *} \mathrm{mean}$ of 3 days $(1 \mathrm{~L}+\mathrm{H})+13$ days $(2 \mathrm{~L}+\mathrm{H})+27$ days $(3 \mathrm{~L}+\mathrm{H})$. Sum equal to 43 days. A total of $21 \mathrm{~L}-$ Name rats.

Nevertheless, comparing $2 \mathrm{C}$ with $2 \mathrm{~L}+\mathrm{H}$ groups significant difference concerning arterial pressure was not found $(p>$ 0.05). In group 3, significant difference in arterial pressure comparing $3 \mathrm{C}$ and $3 \mathrm{~L}$ was only noted beginning on day 13 of experiment, continuing on day 20 and also on day $27(p<0.001)$. Nevertheless, comparing $3 \mathrm{C}$ and $3 \mathrm{~L}+\mathrm{H}$ we had no significant difference on days 13,20 or 28 of experiment $(p>0.05)$. Variations of body weight were considered in Table 2. For day 4 we found variations of $16.6 \%, 14.9 \%$ and $17.3 \%$ respectively to $C, L$ and $L+H$. For day 14 we found variations of $29.4 \%, 14 \%$ and $20.3 \%$ respectively to $\mathrm{C}, \mathrm{L}$ and $\mathrm{L}+\mathrm{H}$. For day 27 we found variations of $32.3 \%, 21.2 \%$ and $21.4 \%$ respectively to $C$, $\mathrm{L}$ and $\mathrm{L}+\mathrm{H}$. Then, on day 27 , both $\mathrm{L}$ and $\mathrm{L}+\mathrm{H}$ groups had similar deficit of about $1 / 3$ in gain of weight when compared to control groups $(p<0.05)$. Estimating cardiac weight (Table 4), we also utilized a relation of cardiac weight (mg)/body weight $(\mathrm{g})$ to eliminate weight interference of each animal in our evaluations. Our results did not show significant difference on days 4 and 14 of experiment $(p>0.05)$. Nevertheless, on day 28 , the $\mathrm{L}+\mathrm{H}$ group presented a near significant cardiac hypertrophy compared with the control group $(p=0.052)$. In the $L$ group, cardiac hypertrophy was not significant probably because of the wide estimated standard error of arithmetic mean.

\section{Pathohistological results}

Concerning histological myocardial alterations, in $1 \mathrm{~L}$ (day 4) we found myocardial abnormalities and lesions mainly in right ventricles while in $1 \mathrm{~L}+\mathrm{H}$ we could not identify myocardial abnormalities or lesions in myocardial tissue. In all control groups, perivascular connective tissue was visualized as more delicate and granular than in L-Name groups and also in group $3 \mathrm{~L}+\mathrm{H}$ (day 28) (Figure). The fibroses (reactive and reparative) in $1 \mathrm{~L}$ were

Table 4 Cardiac weight during the experiments (mean/standard error of mean)

\begin{tabular}{|c|c|c|c|c|c|}
\hline & Control & L & p & $L+H$ & p \\
\hline \multicolumn{6}{|c|}{ Group 1: Control $(n=6) ; L(n=7) ; L+H(n=7)$} \\
\hline CW & $1.21 / 0.03$ & $1.28 / 0.07$ & $>0.05$ & $1.19 / 0.07$ & $>0.05$ \\
\hline CW/ BW & $\begin{array}{c}4.19 / 0.12 \\
(\max =4.51 / \min =3.8)\end{array}$ & $\begin{array}{c}4.61 / 0.3 \\
(\max =6.04 / \mathrm{min}=3.59)\end{array}$ & $>0.05$ & $\begin{array}{c}4.59 / 0.31 \\
(\max =5.71 / \min =3.73)\end{array}$ & $>0.05$ \\
\hline \multicolumn{6}{|c|}{ Group 2: Control ( $n=4$, two animals could not be considered); $L(n=7) ; L+H(n=6)$} \\
\hline CW & $1.14 / 0.07$ & $1.16 / 0.05$ & $>0.05$ & $1.42 / 0.11$ & $>0.05$ \\
\hline $\mathrm{CW} / \mathrm{BW}$ & $\begin{array}{c}3.05 / 0.62 \\
(\max =5.18 / \min =2.13)\end{array}$ & $\begin{array}{c}2.53 / 0.11 \\
(\max =3.03 / \mathrm{min}=2.14)\end{array}$ & $>0.05$ & $\begin{array}{c}2.88 / 0.07 \\
(\max =3.18 / \min =2.68)\end{array}$ & $>0.05$ \\
\hline \multicolumn{6}{|c|}{ Group 3: Control $(n=6) ; L(n=8) ; L+H(n=7)$} \\
\hline CW & $1.38 / 0.1$ & $1.4 / 0.06$ & $>0.05$ & $1.44 / 0.09$ & $>0.05$ \\
\hline CW/ BW & $\begin{array}{c}4.41 / 0.23 \\
(\max =5.15 / \min =3.6)\end{array}$ & $\begin{array}{c}5.51 / 0.45 \\
(\max =7.29 / \min =3.99)\end{array}$ & $>0.05$ & $\begin{array}{c}5.5 / 0.29 \\
(\max =6.53 / \min =4.39)\end{array}$ & $=0.052$ \\
\hline
\end{tabular}

L: submitted to L-Name; L + H: submitted to L-Name + hydralazine; CW: cardiac weight; CW/BW: relation of cardiac weight/body weight; min: minimum value; max maximum value; $p=$ test of similarity evaluating the probability of arterial pressure in control group compared with groups submitted to L-Name and L-Name + hydralazine being equal to zero. 


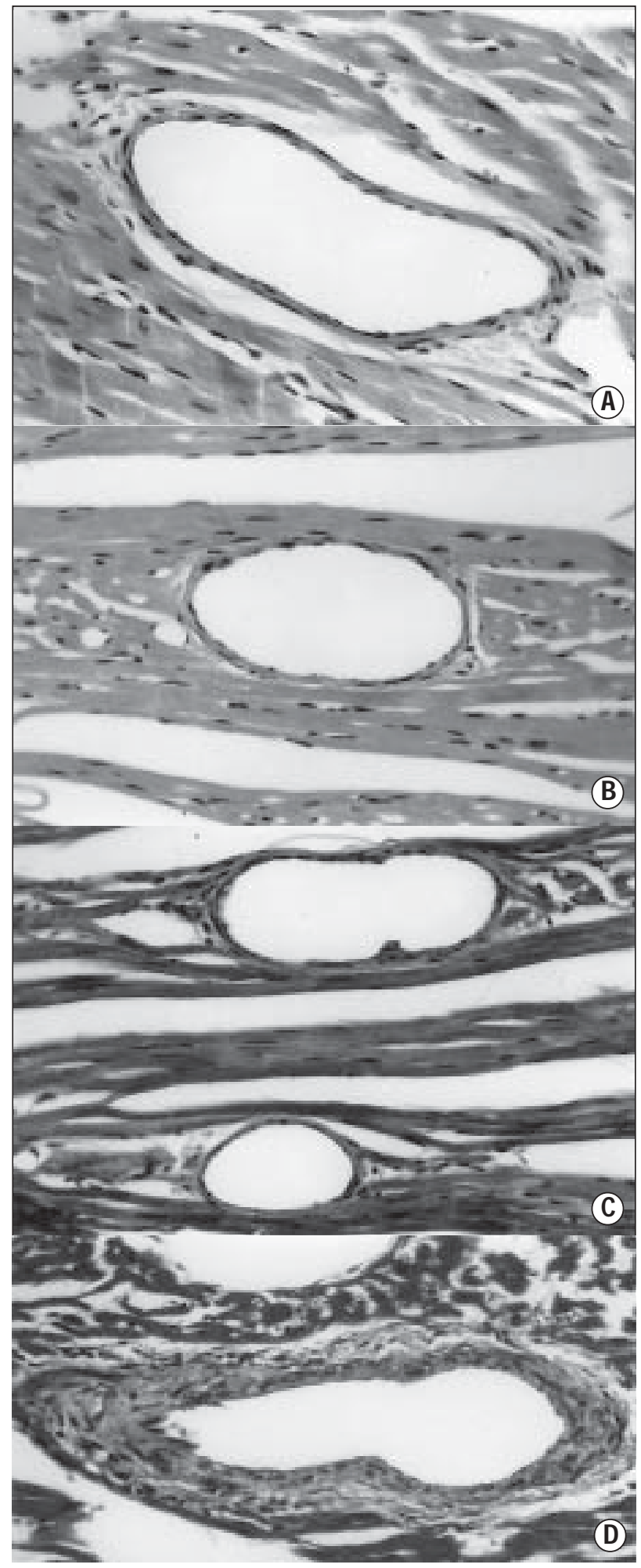

Figure - $A$ - Normal vessels in control rat's myocardium (hematoxilin-eosin, 400x); $B$ - Normal vessels in myocardium of rats submitted concomitantly to L-Name and hydralazine during 4 days (hematoxilin-eosin, 400x); C - Normal vessels in myocardium of rats submitted concomitantly to L-NAME and hydralazine during 14 days (Masson's trichrome, 400x); D - Abnormal arterial vessels in rats submitted concomitantly to L-Name and hydralazine during 28 days. In D, note proliferation of smooth muscle cells, proliferation of cells in the tunicae intima and also thickness of arterial wall with degenerative fibrotic process (Masson's trichrome, 400x) less frequent than in $2 \mathrm{~L}$ and in $2 \mathrm{~L}$ less frequent and less apparent than in $3 \mathrm{~L}$. In $1 \mathrm{~L}$ vascular abnormalities were generally in a more initial state and not so common as in $2 \mathrm{~L}$, and so on. However, in some cases they were very intense. In $1 \mathrm{~L}, 2 \mathrm{~L}$ and $3 \mathrm{~L}$ the right ventricular walls were more affected than the left ventricular walls. In $1 \mathrm{~L}$ - in some cases - we had similar lesions (reparative fibrosis) of those here described in 2L. Nevertheless, in other animals, we found myocardium in a normal or near normal state. In $1 \mathrm{~L}, 2 \mathrm{~L}, 3 \mathrm{~L}$ and $1 \mathrm{~L}+\mathrm{H}, 2 \mathrm{~L}+\mathrm{H}, 3 \mathrm{~L}+\mathrm{H}$ reactions to Weigert's resorcinol fuchsin at repair areas was near null. Considering $3 \mathrm{~L}$ (day 28 ) myocardium presented characteristic lesions (reactive and reparative fibrosis), vascular damage with increasing wall thickness related mainly to proliferation of the arterial smooth muscle cells. The total obliteration of small vessels was noted only in this period. We also observed occurrence of reactive fibrosis between muscle cells of vascular wall. The hypertrophic process of arterial smooth muscle cells and smooth muscle cell's nuclei was observed, which probably contributes to the thickness of arterial wall. Proliferation of cells in the intimal layer and its thickening were also observed. In $3 \mathrm{~L}+\mathrm{H}$ (day 28) we also observed similar vascular abnormalities described for $3 \mathrm{~L}$ subgroup. Nevertheless, it was observed less frequently and less apparently. In subgroup $3 \mathrm{~L}+\mathrm{H}$, we did not identify total vascular obstructions. Reparative fibrosis (infarct areas) was not noted in $3 \mathrm{~L}+\mathrm{H}$ and reactive fibrosis occurred mainly in perivascular region (Figure).

\section{Discussion}

In the present work, using NO systemic blockage (via L-Name) we have identified thickening in vascular wall, perivascular and myocardial fibrosis. At least part of our results are similar to those demonstrated by Hocher et al. (13) in renovascular hypertension and also by Felix et al. (7) using angiotensin II. Hocher et al. (13) suggested that in renovascular hypertension stimulation of endothelin receptor-A (ETA) was related to abnormalities in media/lumen ratio of intramyocardial vessels. Treatment of these renovascular hypertensive rats with ETA antagonist prevented this alteration. In the same work, stimulation of endothelin receptor-B (ETB) was related to increase of fibrotic tissue in left ventricle, however, had no influence in perivascular fibrosis and treatment of these renovascular hipertensive rats with ETB antagonist avoids this alteration. ET-1 promotes growth of cardiomyocytes and induces colagen synthesis (13). 
NO blockage also promotes vasoconstriction, myocardial fibrosis, cellular proliferation and hypertrophy $(6,14)$. Angiotensin II stimulates the synthesis of endothelin-1 (ET-1) in many cellular types including cardiomyocytes. ET-1 causes contraction and mitogenesis at least in mesanglial cells. NO is known to inhibit endothelial cell ET-1 production and this occurs probably via cGMP dependent mechanism. Most endothelial cells express only ET-B receptors. ET-A receptors are widely distributed in vascular smooth muscle cells. Stimulation of ET-A receptor mediates most of the vasoconstrictor response to endothelins. NO counteracts with the vasoconstrictor effect of ET-1. Human and animal studies have suggested that there is a feedback mechanism between ET-1 and NO synthesis that acts reciprocally to regulate vascular tone (15). Almost all biological actions of angiotensin II were considered mediated by angiotensin receptor-I. However, nitric oxide releases because high level of angiotensin II has been recently attributed to angiotensin receptor-II. In angiotensin dependent hypertension the hypotensive effect occurred at least in part because of angiotensin receptor type 2 . Then we have a contraregulatory protector angiotensin receptor type 2 effect mediated by nitric oxide (16).

Considering all these results together, it is probable, in L-Name model, that the involvement of angiotensin II in myocardial remodeling is mediated - at least partially - by the paracrine cardiac endothelin system promoting tissue fibrosis in the heart. Our data suggests that lesions in cardiac tissue occurred in L-Name model not mainly because of the hypertensive process, since in nitric oxide blockade/not hypertensive rats the same lesions occurred.

Sander et al. (17) showed that L-NMMA and L-Name significantly increase the arterial pressure of human beings. Nevertheless, blood pressure returns to baseline 24 hours after stopping infusion or after administration of L-arginine $(200 \mathrm{mg} / \mathrm{kg})$. They also showed that L-Name $(4 \mathrm{mg} / \mathrm{kg}, 60$ minutes of infusion time) was much more effective than L-NMMA $(50 \mathrm{mg} / \mathrm{Kg}, 120$ minutes of infusion time). Using these doses the greatest increase of mean arterial pressure was $23 \pm 3 \mathrm{mmHg}$ (L-Name) and $15 \pm 2 \mathrm{mmHg}$ (L-NMMA). The largest effect of LName was on diastolic blood pressure with a maximum value of $109 \mathrm{mmHg}$. D-Name and D-arginine had no effect in blood pressure. Also $\alpha$-adrenergic blockage reversed in $40 \%$ the peak increase of blood pressure after L-Name infusion meaning that this increase is in part sympathetically mediated. These authors conclude that, in human beings - although inhibition of endotheliumdependent vasodilatation is the primary mechanism underlying the initiation of the hypertensive response to L-Name - the sympathetic nervous system plays an important role in the full expression and maintenance of this large blood pressure-raising effect.

Mice submitted to endotelial nitric oxide sinthases (eNOS) knockout present an arterial pressure level raising in about $15 \mathrm{mmHg}$ (18) or $47 \mathrm{mmHg}$ (19) compared with control animals. Also the basal arterial pressure is reduced in about $20 \mathrm{mmHg}$ in mice with eNOS overexpression (18).

In this work, concerning L-Name group on day 28, fibrosis and lesions were greater than those we found in a previous work on day 21 and inferior to that found on day 35 (6). Lesions on day 35 (6) were more similar to that found on day 43 and were very wide (20). Our previous $(6,20)$ and present data suggest that after day 28 of submission to L-Name (concentration $750 \mathrm{mg} / \mathrm{l}$ in drinking water) the cardiac tissue becomes more susceptible reducing its stability. So, considering the data here presented and other results $(6,20)$, we can say that the LName model presents progressive lesions directly proportional to the time of submission. In this model the right ventricular wall is more affected.

In present work, on all days of submission to L-Name the reaction to Weigert's resorcinol fuchsin (with or without oxon) in myocardial or perivascular fibrotic areas is nearly null. In a previous work, however, on days 35 and 43 the lesions were greatly reactive and using oxon, a more intense reaction was seen $(6,20)$. This indicates that initial repair in L-Name model is made more by collagen than by elastic fibers and in extended periods (days 35 and 43) a substantial amount mainly of oxitalanic fibers in reparative region was observed, which may originate diastolic deficiency $(6,20)$.

Concerning day 28, the group $\mathrm{L}+\mathrm{H}$ presented a near significant cardiac hypertrophy compared with control group ( $p=0.052$ ). This may suggest that blockage of hypertension using hydralazine does not avoid heart hypertrophy. Then, these results may contribute to the knowledge that the hypertrophic process is mainly due to nitric oxide deficit. In human species, the increase of load in arterial pressure induces hypertrophy at left ventricular wall. In some patients the heart may double its weight; nevertheless, in others - with the same arterial overloaded pressure - even after several years the heart may suffer just a slight hypertrophy (21). In the present 
work, a non-significant difference in heart weight comparing $3 \mathrm{C}$ with $3 \mathrm{~L}$ groups probably occurred because $\mathrm{L}$ group presented a wide standard error of mean (SEM = 0.45 ), because not all animals developed significant cardiac hypertrophy.

Arnal et al. (22) found that both hypertension and myocardial abnormalities were avoided using concomitant submission of L-Name and angiotensin convert enzyme inhibitor trandolapril or calcium blocker channel verapamil. These results were not confirmed by our present results and neither by those of Numaguchi et al. (1) or Moreno Jr. et al. (3-5). Moreno Jr. et al. (3-5), utilizing L-Name + enalapril, found that angiotensin convert enzime inhibitor avoided arterial hypertension and left ventricular hypertrophy, nevertheless, did not prevent myocardial lesions. In the present work, on day 28 of submission in $3 \mathrm{~L}+\mathrm{H}$ group (L-Name $750 \mathrm{mg} / \mathrm{l}+$ hydralazine $120 \mathrm{mg} / \mathrm{l}$ ), similar vascular abnormalities were described for 3L. Nevertheless, the abnormalities in $3 \mathrm{~L}+$ $\mathrm{H}$ were less frequent and less apparent. Group $3 \mathrm{~L}$ presented severe vascular obstructions, infarct and repair areas, however, in group $3 \mathrm{~L}+\mathrm{H}$ these lesions were not seen. In $3 \mathrm{~L}+\mathrm{H}$ we could only see vascular abnormalities. Results on day 28 are also similar to abnormalities and lesions occurring in human arteriosclerosis (23). NO was also suggested to be an antiatherogenic, antiproliferative and antithrombotic factor (15). Numaguchi et al. (1), using concomitant submission to L-Name and hydralazine in rats ( 56 days), found necrotic areas, reparative fibrosis and vascular obstructions in myocardium. However, in doses of L-Name $100 \mathrm{mg} / \mathrm{l}$ the lesions were greater than those found in L-Name $1 \mathrm{~g} / \mathrm{l}+$ hydralazine $120 \mathrm{mg} / \mathrm{l}$. In doses of $\mathrm{L}-\mathrm{Name} 1 \mathrm{~g} / \mathrm{l}$ the lesions were greater than those found in doses of L-name $100 \mathrm{mg} / \mathrm{l}$. In the present work on day 28 of concomitant submission to L-Name $750 \mathrm{mg} /$ I + hydralazine $120 \mathrm{mg} / \mathrm{l}$ we did not find necrotic areas, reparative fibrosis and vascular obstructions found by Numaguchi et al. (1) on day 56 of submission. Our results suggest that the morbid process in the present model can be postponed by using hydralazine which, however, does not avoid these events after moderate or long-term experimental submission to L-Name.

\section{Acknowledgements}

This article was supported by Capes, CNPq, IPPMG/ UFRJ, CIC-HUCFF/UFRJ and AXV. During this work, the main author had a Ph.D. fellowship from Capes, Brasília/ Brazil. The main author thanks his Lord and God Jesus Christ and the $1^{\text {st }}$ Baptist Church of Niterói, RJ.

\section{References}

1. N umaguchi, K. et al. Chronic inhibition of nitric oxide synthesis causes coronary microvascular remodeling in rats. $\mathrm{H}$ ypert., 26(1): 957-962, 1995

2. Ignarro, L.J. Role of nitric oxide in the pathophysiology of hypertension; physiology and pathophysiology of nitric oxide. Kidney Intern., 49(S55): S2-S5, 1996.

3. Moreno Jr., H. et al. Enalapril does not prevent the myocardial ischemia caused by the chronic inhibition of nitric oxide. Eur. J. Pharmacol., 287: 93-96, 1995.

4. Moreno Jr., H. et al. C hronic nitric oxide inhibition as a model of hypertensive heart muscle disease. Basic Res.Cardiol.,91(3): 248-255, 1996

5. Moreno Jr., H . et al. N on-specific inhibitors of nitric oxide synthase cause myocardial necrosis in the rat. Clinic Exp. Pharmacol. Physiol., 24: 349-352, 1997.

6. Xavier-Vidal, R. et al. Estudo anatomopatológico experimental em mio cárdio de animais submetidos à hipertensão arterial via bloqueador da síntese do óxido nítrico. Rev. Port. Cardiol., 17(2): 381-391, 1999.

7. Felix, J. et al. Myocardial fibrosis associated with aldo sterone or angio tensin II administration: attenuation by calcium channel blockage. J. Mol. Cell Cardiol., 30: 475-483, 1998.
8. Ribeiro, M .O .et al. C hronic inhibition of nitric oxide synthesis. $A$ new model of arterial hypertension. H ypert., 20:298-303, 1992.

9. Fullme, H.M. et al. O xytalan connective tissue fibers: a review. J. Oral Pathol., 3: 291, 1974.

10. Corrêa, E.M. Estudo histoquímico e ultra-estrutural da matriz extracelular na córnea de embriões de Gallus gallus dom. Estudo experimental em aves. Rio de Janeiro, 1986 Tese (mestrado) - Universidade de Estado do Rio de Janeiro.

11. D olber, P.C . \& Spach, M.S. Picro scirius red staining of cardiac muscle following phosphomolybdic acid treatment. Stain Technol., 62: 23-26, 1987.

12. Dolber, P.C. \& Spach, M.S. Conventional and confocal fluorescence microscopy of collagen fibers in the heart. The Journal of H isto-Tecnol. Cytochem., 41: 465-469, 1993.

13. Hocher, B. et al. Endothelin system-dependent cardiac remodeling in renovascular hypertension. Hypert., 33:816822, 1999.

14. Kolpakov,V. et al. N itric oxide-generating compounds inhibit total protein and collagen synthesis in cultured vascular smooth muscle cells. Circulation Research, 76(2): 305-309, 1995. 
15. Bataineh, A.\& Raij, L. A ngiotensin II, nitric oxide, and end-organ damage in hypertension. Kidney Intern.,54(68):S14-S19, 1998.

16. Carey, R.M . et al. N itric oxide: a physiolo gical mediator of the type 2 (AT2) angiotensin receptor. Acta Physiol. Scand., 168: 65-71, 2000.

17. Sander, M. et al. A large blood pressure-raising effect of nitric oxide synthase inhibition in humans. H ipert.,33:937-942,1999.

18. So ubrier, F. N itric oxide synthase genes: candidate genes among many others. H ypert., 33: 924-926, 1999.

19. Stauss, H .M. et al. Blo od pressure control in eN O S knock-out mice: comparison with other species under $\mathrm{N} O$ blockade. Acta Physiol. Scand., 168: 155-160, 2000.
20. X avier-Vidal, R. A lterações morfológicas do miocárdio devidas a hipertensão arterial induzida por inibidor da síntese do óxido nítrico. Estudo experimental em ratos. N iterói, RJ, 1995. Dissertação (Mestrado em Patologia) - Hospital Universitário Antônio Pedro, Universidade Federal Fluminense.

21. McGee, J.O 'D. et al. 0 xford textbook of pathology; pathology of systems. 0 xford: 0 xford U niversity Press, 1992.

22. Arnal, J.F. et al. C ardiac weight in hypertension induced by nitric oxide synthase blockade. Hypert., 22(3): 380-387, 1993.

23. Contran, R.S. et al. Robbins: pathologic basis of disease. $5^{\text {th }}$ edition. Philadelphia:W B Saunders Company, 1994. 